\title{
Development of maternal and neonatal composite outcomes for trials evaluating timing of delivery in women with pre-eclampsia
}

\author{
Fiona Fong ${ }^{1}$, Ewelina Rogozinska', John Allotey ${ }^{1 *}$, Steve Kempley ${ }^{2,3}$, Divyen Shah ${ }^{3}$, Shakila Thangaratinam ${ }^{1,4}$ \\ From 2nd Clinical Trials Methodology Conference: Methodology Matters \\ Edinburgh, UK. 18-19 November 2013
}

Composite outcomes comprising more than one clinically relevant end point are used in clinical trials where there is no single important outcome or the outcome is very rare. Pre-eclampsia is associated with significant maternal and neonatal complications and delivery is often expedited to minimise complications. There is a need for a randomised trial to evaluate the timing of delivery in women with mild to moderate pre-eclampsia at late preterm gestation. No single outcome has been identified to be the most clinically important, reflecting the multisystemic nature of pre-eclampsia. We developed composite maternal and neonatal outcomes to be considered as the primary outcome measure for a clinical trial in this area.

A two-generational Delphi method was used to identify these clinically important maternal and neonatal outcomes. Composite outcomes were developed based on biological plausibility, independence from each other, equal importance and frequency of occurrence. The final maternal composite outcome included maternal death, eclampsia, stroke or reversible ischaemic neurological deficit, pulmonary oedema, major obstetric haemorrhage, infusion of a third anti-hypertensive or need for positive ionotropic support, HELLP (haemolysis, elevated liver enzymes and low platelets) syndrome and placental abruption; and the neonatal composite outcome included neonatal death, respiratory distress syndrome needing ventilator support and neurological outcomes as cystic periventricular leukomalacia and grade III/IV intraventricular haemorrhage.

The composite outcomes developed will enable clinical trials on the timing of delivery in women with mild to

'Women's Health Research Unit, Barts and the London School of Medicine and Dentistry, London, UK

Full list of author information is available at the end of the article moderate pre-eclampsia to provide robust estimates for the intervention to be implemented in clinical practice.

\section{Authors' details}

'Women's Health Research Unit, Barts and the London School of Medicine and Dentistry, London, UK. ${ }^{2}$ Centre for Paediatrics, Blizard Institute, Barts and the London School of Medicine and Dentistry, London, UK. ${ }^{3}$ Neonatal Unit, Barts Health NHS Trust, London, UK. ${ }^{4}$ Multidisciplinary Evidence Synthesis Hub, Queen Mary University London, London, UK.

Published: 29 November 2013

\section{doi:10.1186/1745-6215-14-S1-P50}

Cite this article as: Fong et al:: Development of maternal and neonatal composite outcomes for trials evaluating timing of delivery in women with pre-eclampsia. Trials 2013 14(Suppl 1):P50.
Submit your next manuscript to BioMed Central and take full advantage of:

- Convenient online submission

- Thorough peer review

- No space constraints or color figure charges

- Immediate publication on acceptance

- Inclusion in PubMed, CAS, Scopus and Google Scholar

- Research which is freely available for redistribution

Submit your manuscript at www.biomedcentral.com/submit
C Biomed Central
C Biomed Central

(c) 2013 Fong et al; licensee BioMed Central Ltd. This is an Open Access article distributed under the terms of the Creative Commons Attribution License (http://creativecommons.org/licenses/by/2.0), which permits unrestricted use, distribution, and reproduction in any medium, provided the original work is properly cited. 